\title{
BLOOD GROUPS IN INDIA
}

\author{
EILEEN W. E. MACFARLANE AND S. S. SAREAR \\ Lniversity of Michigan, Ann Arbor, and Bose Research Institute, Calcutta
}

INTRODUCTION

Blood group data have been obtained from 2120 aborigines in the Peninsula of India. Although this is only a beginning the results are of peculiar interest because of the wide variation in the blood group frequencies found. A hundred or over have been tested in each of twelve tribes: Bagdi, 107; Bhil, 140; Chenchu, 100; Kanikkar, 211; Korku, 140; Mälé, 235; Maria Gond, 123; Munda, 120; Oraon, 155; Paniyan, 250; Santal, 339; Toda, 200. Four of these who live south of the Deccan are italicized. Table 1 give the blood group percentages and the frequencies $p, q$, and $r$ of the genes concerned. It will be seen that where $p$ and $q$ are concerned three groups occur within which the tribes show no significant differences. These are shown in table 2 and consist of (1) Kanikkar, Mālé and Chenchu; (2) Bagdi, Maria Gond, Munda and Santal; (3) Bhil, Korku and Toda. This leaves (4) the Paniyan distinguished by a particularly high value for $p$ and (5) the Oraon with low $\mathrm{p}$ who resemble the Chenchu, Kanikkar and Mālé in a high value for $r$ and the Santal in $q$, but they stand distinct from all others because of the very low value for $p$. The Todas have a slightly higher value for $r$ than the Bhils and Korkus.

\section{ANALYSIS OF DATA}

The Paniyans (Aiyappan) of the Western Ghats of South Nalabar contain a marked negrito element. The high percentage of group A, together with little of group B, were 
taken as a confirmation of their racial affinities with the Australians. The large amount of A was attributed (Macfarlane, '36) to inbreeding in an isolated community where one fertile family may have a large effect. As shown in table 1 the lowest percentage of group B for any tribe was found

TABLE 1

Blood group percentages and gene frequencies of Indian aborigines.

\begin{tabular}{|c|c|c|c|c|c|c|c|c|c|c|}
\hline PEOPLES & No. & 0 & A & $B$ & $A B$ & $p$ & $q$ & $r$ & $D / \sigma$ & IN VESTIGATOR \\
\hline Bagdi & 107 & 29.91 & 24.23 & 35.52 & 10.28 & .189 & .262 & .547 & 0.1 & $\begin{array}{l}\text { Sarkar and } \\
\text { Macfariane }\end{array}$ \\
\hline Bhil & 140 & 18.6 & 23.6 & 41.4 & 16.4 & .218 & .344 & .431 & 0.3 & Macfarlane \\
\hline Chenehu & 100 & 37.0 & 37.0 & 18.0 & 8.0 & .252 & .133 & .608 & 0.4 & $"$ \\
\hline Kanikkar & 211 & 51.18 & 18.48 & 29.86 & 0.47 & .120 & .185 & .715 & 2.2 & Karunakaran \\
\hline Korku & 140 & 20.0 & 28.6 & 37.9 & 13.6 & .250 & .313 & .447 & 0.4 & Macfarlane \\
\hline Mālé & 235 & 42.13 & 25.53 & 26.81 & 5.53 & .167 & .181 & .649 & 0.3 & Sarkar \\
\hline Maria Gond & 123 & 28.46 & 26.02 & 34.14 & 11.38 & .204 & .257 & .524 & 0.3 & Macfarlane \\
\hline Munda & 120 & 33.33 & 30.00 & 29.17 & 7.50 & .219 & .214 & .577 & 0.6 & $"$ \\
\hline Oraon & 155 & 47.10 & 12.90 & 34.84 & 5.16 & .088 & .219 & .686 & 0.8 & Sarkar \\
\hline Paniyall & 250 & 20.0 & 62.4 & 7.6 & 10.0 & .461 & .078 & .447 & 1.1 & Aiyappan \\
\hline Santal & 339 & 33.04 & 20.94 & 34.81 & 11.21 & .160 & .249 & .575 & 1.6 & Sarkar \\
\hline Toda & 200 & 29.5 & 19.5 & 38.0 & 13.0 & .157 & .278 & .545 & 1.5 & Pandit \\
\hline
\end{tabular}

TABLE 2

Tribes grouped according to blood group frequencies.

\begin{tabular}{c|c|c|c|c}
\hline \multicolumn{1}{c|}{ I } & II & III & IV & V \\
\hline Paniyan & $\begin{array}{l}\text { Chenchu } \\
\text { Kanikkar } \\
\text { Mãlé }\end{array}$ & Oraon & $\begin{array}{l}\text { Bagdi } \\
\text { Maria Gond } \\
\text { Munda } \\
\text { Santal }\end{array}$ & $\begin{array}{l}\text { Bhil } \\
\text { Korku } \\
\text { Toda }\end{array}$ \\
\hline $\begin{array}{l}\text { p high } \\
\text { q \& r low }\end{array}$ & $\begin{array}{l}\text { r high } \\
\text { p \& q low }\end{array}$ & $\begin{array}{l}\text { r high } \\
\text { plow }\end{array}$ & $\begin{array}{l}\text { p, q, r } \\
\text { medium }\end{array}$ & q high \\
\hline
\end{tabular}

among the Paniyans and the lowest percentage of group A among the Oraons. Both are Dravidian speaking. The Paniyans are food-hunters who are just beginning to adopt agriculture while the Oraons are primitive agriculturalists. From physical measurements (table 3) the Paniyans (Thurston) 


\begin{tabular}{|c|c|}
\hline & 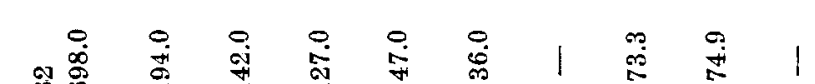 \\
\hline & 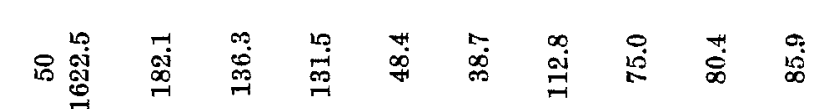 \\
\hline & 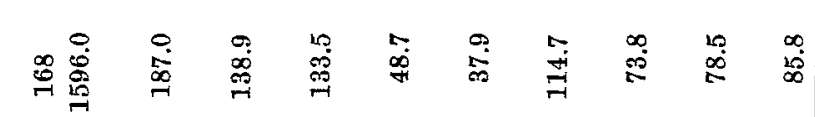 \\
\hline & 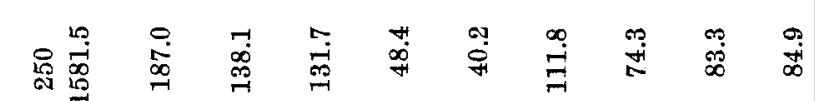 \\
\hline & 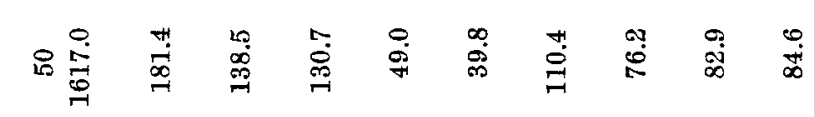 \\
\hline & 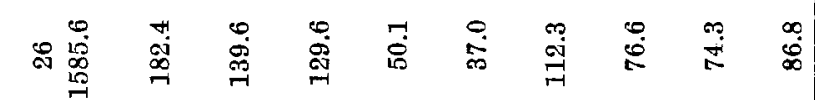 \\
\hline & 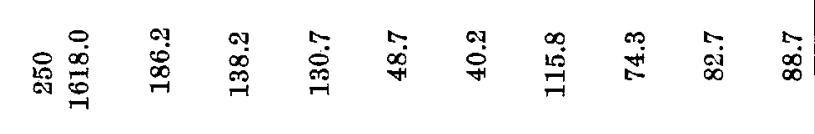 \\
\hline & 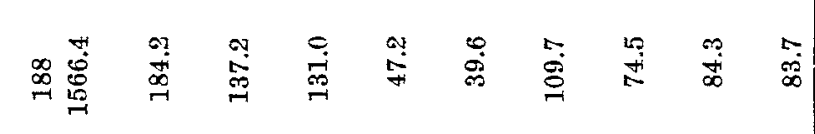 \\
\hline & 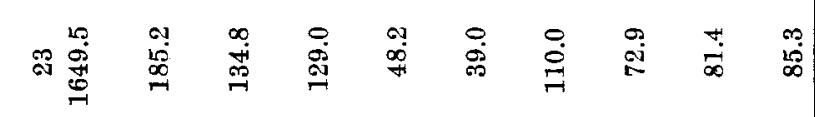 \\
\hline & 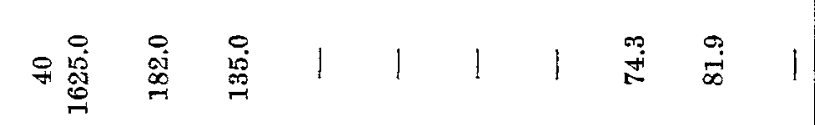 \\
\hline & 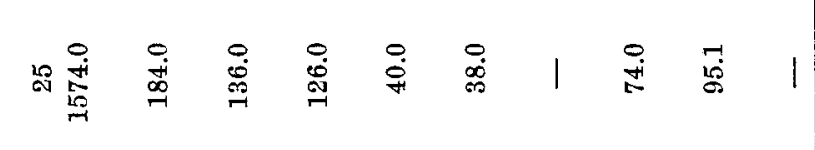 \\
\hline & $\frac{\partial}{\partial}$ \\
\hline & 2 \\
\hline
\end{tabular}


are found to be on the average $46 \mathrm{~mm}$. shorter in stature than the Oraons (Basu, '33-'34), only the Kanikkars are shorter than this. The Paniyans are also the most platyrrhine of all the groups compared in table 3. In blood group distribution the two tribes, Paniyans and Oraons, are diametrically opposed. The Paniyans have probably maintained their racial stock almost unmixed in their isolated mountain retreat. The Oraons have migrated from the South (Roy) within the past few centuries to the Chota Nagpur Plateau in eastern Central India and are at present filtering eastward into Bengal (Sarkar, '36-'37). Although they may have received group B from other peoples on their migrations it is extremely difficult to account for their very low frequency of gene A: They have the next highest frequency of group $O$ to the Kanikkars among the tribes thus far examined and the blood group distribution in these two tribes shows some similarity.

The Oraons and Gonds were called Dravidians by Dalton (1872), Russell ('16) and others who stated that they were later arrivals in Central India than the Mundas. It is not known whether the blood group distribution of the Gonds of the Central Provinces resembles the Oraons or that of the Santals and Maria Gonds. The "Dravidians" whose blood groups were taken by Malone and Lahiri ('29) were a mixture of Oraons, Mundas and Santals from Chota Nagpur.

The Kanikkars belong to the extreme south and migrated within historical times from the Tinnevelly Hills, Madura District to the southern end of the Western Ghats in Travancore (Iyer). They have the shortest stature of the tribes compared here (table 3) and come next to the Paniyans in platyrrhiny. With respect to blood group distribution their position seems to be somewhat akin to the Oraons. A good sample of 211 blood groups, tested by Karunakaran, is given by Iyer, who considers them to show an Australian type of blood group distribution in spite of nearly $30 \%$ of group B. He attributes the high $B$ to intermixture with plainsmen and forest guards. Group B is known to be scarce in Malabar except in the higher castes (Macfarlane, '36) but more fre- 
quent arnong the Tamils. The $30 \%$ of group B among the Kanikkars cannot be regarded as almost completely Tamilian in origin and it is as feasible to suppose that much of their $B$ is proper to them racially and that the related Paniyans have lost their original B (Boyd, '40). Thurston ('07) recorded that intermixture was occurring among the Kanikkars. The Kanikkar blood group data are somewhat anomalous. They present the highest percentage of group $O$ (over 50\%) and the lowest of $\mathrm{AB}$ found in India until now. The value for $\mathrm{D} / \sigma$ is 2.2 which is a high value indicative of genetic inequilibrium or technical defects. The Kanikkar data fall into line with those for the Chenchus and Mālér. Their value for $q$ is 18 , which is still low for India and only the Paniyans and the Chenchus have lower.

In Cochin which lies between Malabar and Travancore one of us tested bloods from 50 "Pre-Dravidians" (Macfarlane, '36). These were republished as "Kadars" by Iyer. Actually the tribal identities were: Pulayans, 45; Kanikkars, 4 and Ulladan, 1.

The Chenchus of the Eastern Ghats between Madras and Hyderabad are classified by physical anthropologists with the South Indian hill tribes. They have $18 \%$ of group B which is more than double that found in the Paniyans (7.6\%), yet they stand closer to the latter with respect to blood groups than any tribe examined. These two are the only Indian aboriginal tribes yet found with less of $B$ than of $A$.

The Chenchu blood group data (Macfarlane, '40) and the anthropometric data of Guha ('35) were obtained from the same locality, Farhabad Hills, Hyderabad, Deccan, while Thurston measured the Chenchus of the Nallamalai Hills in Kurnool. Like Thurston, Macfarlane recorded that Chenchu girls were being enticed by the forest guards. In fact the Chenchus of both the above regions appear from physical features to be mixed. Some amount of B seems to have entered into the Chenchu blood through miscegenation since less was found in those inhabiting the interior of the jungle. The Chenchus, taking into consideration the means found by 
both Thurston and Guha, are the tallest of the aborigines (Todas excepted) compared here and this associated with a somewhat finer nasal index also testifies to racial intermixture. Tribes who have moved further northward appear to have obtained more of the $B$ element than those who have remained in the South although the condition in the Kanikkars weighs against this generalization.

The Mālér on the other hand, Dravidian speaking, now living in isolated hill tops of the Rajmahal Hills in Santal Perganas, Bihar, have retained a fairly high percentage of $O$ but have almost equal doses of the agglutinogens $A$ and $B$. In anthropometric characters they stand next to the Paniyans with respect to stature and nasal index. They show the northernmost thrust of the aborginal group of people with southern affinities before they were overrun by the Mundari speaking peoples. The relationships of the Mălér and the Oraon have been discussed in earlier publications of one of us (Sarkar, '35-'36, '38, '41). This relationship is exactly parallel to that which has been shown above to exist between the Paniyans and Oraons. Bloods were grouped in a few separated villages and a great deal of variation was observed from place to place in blood group distribution (Sarkar, '36-'37). Serologically the Mālér link up with the Chenchus and Kanikkars (table 2) although they have more of B than of A.

The Maria Gonds, Mundas, Bagdis, Santals, Korkus and Bhils show some features in common. All of them possess relatively high percentages of the blood groups $A, B$ and $A B$, with more of $\mathrm{B}$ than $\mathrm{A}$ and with the percentage of $\mathrm{O}$ decreasing proportionally. The Mundas, Santals and Korkus speak Mundari dialects.

The Bison Head Maria Gonds of Bastar State in the east strand near to the Oraons with respect to physical features, there being a very close agreement in stature and nasal index (Roy in Grigson). The average cranial length of the Maria Gonds is somewhat smaller than that in the Oraons which is possibly correlated with the longer facial length of the latter. This apparent relationship is not supported by the blood 
group figures as in the case of the Mālér and Paniyans. On the other hand the blood group figures of the Maria Gonds are not significantly different from those of the Mundas and Santals of Bihar. The Bison Head Maria Gonds are related to the Hill Marias and to the Murias of Bastar (Grigson) who will probably show similar blood group distributions. If these tribes are a branch of the Gond race of the Central Provinces, which is the opinion of most anthropologists then the Santal type of blood group distribution may stretch from Lower Bengal westward across Bihar and the Central Provinces and south to the Godavari River, with the distinctive Oraon and Mālér islands in Bihar.

The Santals are numerically the largest aboriginal tribe and number over two millions in Bihar, Chota Nagpur and Bengal. More of them have been grouped than of any other tribe. One of us (Sarkar, '36-'37) took three good samples from different places in Santal Perganas and all three show very similar blood group distribution (unlike different samples among the Mālér) with a regular preponderance of group B over $\mathrm{A}$ by 12-15\%. It was also found that some of the lowest occupational Hindu castes in Santal Perganas resemble the Santals closely in blood group distribution.

The Bagdis although they have interbred with the population of Bengal and Bihar show undoubted aboriginal affinities. Both with respect to physical characteristics (Sarkar) and blood groups (Sarkar and Macfarlane) they form an eastern block with the Santals and Mundas. When the data for Macfarlane's paper on Bengal blood groups were shown to Professor J. B. S. Haldane in April, 1938, he wrote in a private communication:

"Applying the $\chi^{2}$ test to the non-caste Hindus, Muslims and Santals we find $n=6, \chi^{2}=5.33 ; \mathrm{P}=.50$. There is no evidence whatever for racial heterogeneity between these samples and they may be grouped together. This group differs significantly from the remainder', (i.e. Brahmins, Kayasthas, Orya Khandaits and Mālér). 
The Mundas appear to be less mixed than the Bagdis and Santals. The fact that they possess the lowest mean stature and highest average nasal index (Basu, '32-'33) among the Bagdis, Maria Gonds, Bhils, and Santals points to the same thing. They are also a large tribe widespread in Bihar and the Eastern States. Only 120 blood groups have been tested among them and these were obtained by one of us (Macfarlane, unpublished) from the Mundas working in the surface ore mines of Singbhum District, South Bihar. Both sexes were tested and they came from the District and from Keonjhar and Mayurbhanj states in the Eastern States Agency. The sample is therefore entirely random and free from the effect of familial strains so prevalent in groups of neighboring villages. There is no evidence from blood grouping to support Eickstedt's ('35) separation of Mundas and Santals as "Kolid Melanids" from the Maria whom he called "Gondid Wedids". In the latter racial group he also placed Oraons and Gonds.

The close relationship between the Bhil and Korku blood group data which were obtained from the Nimar District, eastern Central Provinces, cannot be properly assessed here due to the absence of authentic anthropometric data on the latter. The Bhils however, show a relationship with both the Oraons and Maria Gonds in anthropometric characters though the blood group results show an increase in groups $B$ and $A B$ which cannot be explained properly at present.

The Todas, whose origin and relationships are a much disputed subject, usually possess finer physical featurès than those of the aborigines already mentioned. They have a very tall stature, a very long and broad head (longer than the average Australian) and a nose approaching the Bagdis in nasal index. Though they have a blood group composition somewhat similar to those of the Bhils, Bagdis and the lower castes of North India it is very difficult to draw any conclusion from the existing blood group data. 


\section{DISCUSSION AND CONCLUSION}

The inter-relationship of some of the individual tribes have already been discussed. While it is evident that the South Indian tribes stand distinct serologically and anthropometrically from those north of the Godavari River (except for the Mālér in Bihar) the chief feature of these blood group distributions is the gradual increase in the frequency of the gene $B$ (q) from the south, north to Bihar and thence westward to the Nimar District in the west of the Central Provinces. There is also an increase in the value of gene $A(p)$ on the east side of India from south to north (except for the Oraons lately from farther South) but not from Bihar to the western Central Provinces. In both these distributions the Todas form an anomalous island of high $A$ and $B$ in South India.

Since in the rest of the world a high percentage of group $\mathrm{O}$ goes with long isolation and $\mathrm{A}$ is found to be most concentrated away from the centres of human distribution in the Eurasian land mass, these blood group distributions in the Indian aboriginal tribes may indicate the spread of this racial stock from South India northward. It no doubt penetrated into the Ganges Valley but was later pushed back to the mountains on the northern border of the Deccan by invaders from the northwest.

The gradient of values for $q$ from 0.08 in Paniyans to 0.35 in Bhils (over four times as much) is equal to the variation in $\mathrm{q}$ for the whole world (minus the Australian aborigines and American Indians) and would be astounding in a single race if that is what these aborigines are. This distribution may help to solve the problem of the increase of one or the other of the blood group genes in different parts of the world (Boyd, '40).

Blood group data cannot be correlated with physical characters; the genetic behavior of the latter is complex and is not so well-known as that of the blood groups. However in consideration of the variations found a second possible ex- 
planation is that there were two aboriginal peoples, one having the physical characters of the Paniyans or Mãlér with a low content of $B$ and the other having the physical characters of the Oraons having a low content of A and more B who took part in the racial make-up of the aboriginal population of India. The Mundari-speaking group of peoples, represented by the Santals and the Mundas probably entered India from outside after the others were established and they were already saturated with both the agglutinogens.

The aborigines speaking the Mundari dialects occupy only a small portion of the eastern Central India and do not seem to have penetrated farther southward into the country. We have blood group data from the Mundari speaking Mundas, Santals and Korkus. The resemblances of the Mundari dialect with that of Mon-Khmer of farther East have been definitely established by the researches of Kuhn (1889) and a common substratum is now recognized at the base of the Mon-Khmer, Munda, Nicobarese and Malacca languages which geographically extend from Cochin China to Nimar in Central Provinces (Grierson). In India the Khasis of Assam have been grouped among the Mon-Khmer speakers. The following table (4) shows the blood group distributions of some of the peoples speaking this widespread linguistic group.

Though nothing definite can be said for any relationships in these blood group distributions because of the paucity of data, all the samples show the presence of both the agglutinogens $\mathrm{A}$ and $\mathrm{B}$ in almost equal doses. The Khasis (Macfarlane, '41) stand apart and show the lowest percentage of B (18.5\%) while their high percentage of A $(35 \%)$ is a characteristic of the Central Chinese, the Tibetans and of the tribes dwelling in the Assam mountains, and may be due to interbreeding. The Khasi data were obtained from Cherrapunji where recent intermixture has been less than in the other areas. The value of $\mathrm{D} / \mathrm{o}$ is also high (1.7) which is indicative of genetic inequilibrium in the population.

In view of the blood group composition of the Mon-Khmer speaking folks given above, it thus appears feasible to suppose 
that the Mundari-speaking peoples entered India well supplied with both the blood groups A and B. The higher percentage of blood group B, now found in some of the Mundari speaking tribes may well be due to intermixture with the aborigines rich in group $B$ who were already present in India. More light on this problem would be obtained from a study of the Nicobarese blood groups. A blood group survey of the

TABLE 4

Blood group distribution of the Mundari-speaking peoples compared with those speaking the Mon-Khmer dialects.

\begin{tabular}{|c|c|c|c|c|c|c|c|c|c|c|}
\hline PEOPIES & so. & 0 & $A$ & B & $A B$ & p & $q$ & $\mathbf{r}$ & $\mathrm{D} / \sigma$ & $\begin{array}{l}\text { INVESTI- } \\
\text { GATOR }\end{array}$ \\
\hline $\begin{array}{l}\text { Mundari: } \\
\text { Korku }\end{array}$ & 140 & 20.0 & 28.6 & 37.9 & 13.6 & .250 & .313 & .447 & 0.4 & Macfariane \\
\hline Santal & 339 & 33.04 & 20.94 & 34.81 & 11.21 & .160 & .249 & .575 & 1.6 & Sarkar \\
\hline Munda & 120 & 33.33 & 30.00 & 29.17 & 7.50 & .219 & .214 & .557 & 0.6 & Macfarlane \\
\hline $\begin{array}{l}\text { Mon-Khmer: } \\
\text { Khasi }\end{array}$ & 200 & 33.0 & 35.0 & 18.5 & 13.5 & .261 & .168 & .563 & 1.7 & $"$ \\
\hline Annamites & 500 & 42.0 & 22.4 & 28.4 & 7.2 & .161 & .198 & .648 & 1.0 & Hirzfeld \\
\hline Tonkin* & 397 & 42.8 & 21.6 & 28.0 & 7.6 & .148 & .187 & .654 & 1.6 & $\begin{array}{r}\text { Hirzfeld \& } \\
\text { Hirzfeld }\end{array}$ \\
\hline $\begin{array}{l}\text { Buginese }^{*} \\
\text { (Celebes) }\end{array}$ & 217 & 34.6 & 30.4 & 27.6 & 7.4 & .218 & .200 & .589 & 0.5 & Lehmann \\
\hline $\begin{array}{c}\text { Macassar* } \\
\text { (Celebes) }\end{array}$ & 195 & 28.7 & 29.7 & 30.8 & 10.8 & .228 & .234 & .536 & 0.1 & $"$ \\
\hline Ambon & 1471 & 55.9 & 20.9 & 20.9 & 2,3 & $.128^{*}$ & $.128^{*}$ & $.747^{*}$ & $1.3 *$ & Bijlmer \\
\hline Javanese & 1.346 & 39.9 & 25.7 & 29.0 & 5.4 & $.178^{*}$ & $.198^{*}$ & $.632^{*}$ & 1.9 & $\begin{array}{c}\text { Bais \& } \\
\text { Verhoef }\end{array}$ \\
\hline
\end{tabular}

* Valnes taken from Boyd's tables ('39).

Andaman and Nicobar Islands should be done as early as possible before the aborigines die out and the laudable efforts of Prof. R. R. Gates ('40) in this direction should be followed up.

\section{ACKNOWLEDGMENT}

We have to thank Dr. B. S. Guha for allowing us to use his unpublished anthropometric data on the Bhils of Central India. 


\section{SUMMARY}

1. Blood group data are compared in samples of over 100 persons from twelve aboriginal tribes in the Peninsula of India: Bagdi, Bhil, Chenchu, Kanikkar, Korku, Mālér, Maria Gond, Munda, Oraon, Paniyan, Santal and Toda.

2. The tribes fall into five groups with respect to blood groups distribution, the Paniyans and Oraons each standing. alone with high and low values for $p$ respectively. Only the Paniyans and Chenchus have less of group B than of group A.

3. Blood group data and physical measurements testify to a relationship between the Paniyans, Kanikkars and Chenchus of South India with the Mālér of Bihar. These are all Dravidian speaking.

4. The Paniyans do not resemble serologically or anthropometrically the Dravidian speaking Oraons of Bihar who have migrated from the South in recent centuries. The Oraons, however, show some similarity serologically with the Kanikkars.

5. The Mālér are also strongly contrasted with their neighbors the Oraons. The Mälér are the northernmost remnant of the tribes with definite southern affinities and the Oraons came to their present habitat later. There is a great variation in blood group distribution in different Mālér villages.

6. The Maria Gonds of Bastar State resemble most the Oraons in physical characters but serologically they fall in with the Mundari-speaking Santals, Mundas and the related Bagdis of Bengal.

7. There is no significant difference between the blood group distributions of the Santals, Mundas, Bagdis, Maria Gonds and some of the lowest occupational Hindu castes in Bihar and South Bengal. Anthropometric data indicate that the Mundas are less mixed than the Bagdis and Santals.

8. The Bhils and Korkus of the Central Provinces have very high percentages of groups B and AB. The Todas in the South also have a similar blood group distribution. The affinities of these three tribes are not yet clear. 
9. There is in general an increase in the frequencies of genes $A$ and $B$ from the south northward and in group $B$ and $A B$ from east to west across Central India. It is suggested that there may have been two original racial stocks one resembling the Paniyan or Mālér, with little of $B$, and the other resembling the Oraons, with little of $A$ and plenty of $B$. The Santals and related Mundari-speaking peoples possibly entered India later.

10. The Mundari-speaking peoples, whose language possesses a common substratum with the Mon-Khmer dialects, resemble the Mon-Khmer speaking tribes of South-east Asia in having a significant amount of both the agglutinogens $\mathrm{A}$ and $B$. The Khasi data show a somewhat lesser content of $B$ and more of the Tibetan and Central Chinese type of distribution.

\section{LITERATURE CITED}

Aiyappan, A. 1936 Blood groups of the Paniyans of the Wynaad Plateau. Man, 255.

Basu, P. C. 1932-1933 The racial affinities of the Mundas. Trans. Bose Res. Inst., VIII, 211-247.

1933-1934 The racial affinities of the Oraons. Trans. Bose Res. Inst., IX, 132-176.

BIJLMER, H. J. T. 1935 The relation of blood-groups to race and some particulars of the South-west Pacific. J. Roy. Anthrop. Inst., LXV, 123-131.

Povd, W. C. 1939 Tabulae Biologicae, XVIY, 113-240.

1940 Critique of the methods of classifying mankind. Am. J. Phys. Anthrop., XXVII, 333-364.

Dalton, E. T. 1872 Descriptive Ethnology of Bengal. Calcutta.

Gates, R. R. 1940 Blood groups from the Andamans. Man, 63.

GrIERson, G. A. 1906 Linguistic Survey of India. I and II. Calcutta.

Grigson, W. V. 1938 The Maria Gonds of Bastar. Oxford.

GunA, B. S. 1935 The Racial affinities of the Peoples of India. Census of India, I, Pt. 3, Calcutta.

IYER, L. A. K. 1939 The Travaneore Tribes and Castes. II and III, 1941, Trivandrum.

KuнN, E. 1889 Beiträge zur Sprachenkunde Hinterindiens. Sitzber. Bayer Akad. Wissen. II, Munich.

Mactarlane, E. W. E. 1936 Preliminary note on the blood groups of some Cochin castes and tribes. Current Seience, IV, 653-654.

1937 Supplementary note on the blood groups of the aborigines of Bihar. Current Seience, VI, 284. 
Macparlane, E. W. E. 1938 Blood group distribution in India with special reference to Bengal. J. Geneties, XXXVI, 225-237.

1940 Blood grouping in the Deccan and Eastern Ghats. J. Roy. Asiatic Soc. Bengal, Science, VI, 39-49.

1941 Tibetan and Bhotia blood group distribution. J. Roy. Asiatic Soc. Bengal (in press).

Malone, R. H., AND M. N. Lafiri 1929 The distribution of the blood groups in certain races and castes of India. Ind. J. Med. Res., XVI, 963-968.

Rox, S. C. 1915 The Oraons. Ranchi.

Russell, R. V. 1916 The Tribes and Castes of Central Provinees of India. I. London.

SARKAR, S. S. 1935-1936 The racial affinities of the inhabitants of the Rajmahal Hills. Trans. Bose Res. Inst., XI, 123-152.

1937 Preliminary note on the blood groups of the aborigines of Bihar. Current Science, VI, 283.

1936-1937 Blood grouping investigations in India, with special reference to Santal Perganas, Bihar. Trans. Bose Res. Inst., XII, 89-101.

1938 The Mālér of the Rajmahal Hills. Calcutta.

1941 Analysis of Indian blood group data, with special reference to the Oraons. Trans. Bose Res. Inst. (in press).

Thurston, E. 1909 Castes and Tribes of Southern India. I. Madras.

von EICKSTEDT, E. F. 1935 The position of Mysore in India's racial history. The Mysore Tribes and Castes, I. Bangalore. 